period in a locum senior registrar post may also count towards higher training (see 4 above). No other type of postmembership experience is deemed to count towards higher training.
DR R. HERRIngton, Honorary Secretary, Joint Committee on Higher Psychiatric Training, Royal College of Psychiatrists

\title{
Miscellany
}

\section{The Sainsbury Mental Health Initiative}

A new mental health initiative organised and funded by the Sainsbury Centre for Mental Health, with support from the Department of Health, was launched in February 1994. Over the next three years the Sainsbury Mental Health Initiative will make $£ 3$ million avallable as grants, to develop community based mental health services throughout England. Any agency trying to provide a service to adults with severe mental illness is encouraged to submit its proposals for funding. The Initiative's steering group will be chaired by Sir Roy Griffiths. The Sainsbury Centre for Mental Health is the new name for Research and Development for Psychiatry (RDP) - a charity which has been working to improve the quality of life for people with severe mental health problems since 1985 . Further information: The Sainsbury Centre for Mental Health, 134-138 Borough High Street, London SEl 1LB.

\section{British Medical Anthropology Review}

The Review will replace and continue the British Medical Anthropology Society Newsletter, founded in 1976. It will include original papers and book reviews and will continue the informational and networking activities of the British Medical Anthropology Society. It is intended to publish the Review twice a year. Further information: Dr Murray Last, Department of Anthropology, University College, Gower Street, London WC1E 6BT.

\section{The mental health debate}

OPENMIND, the mental health magazine published by MIND (National Association for Mental Health), is keen to hear from psychiatrists who would like to join the mental health debate in its pages. The magazine is read by a wide range of mental health professionals, although psychiatrists are currently under-represented, and is also read by people who have used mental health services and by their relatives and carers. It aims to provide information, campaign for better ser- vices and, through first-hand accounts, to provide an insight into service users' experiences of mental distress. Annual subscriptions (six issues a year): $£ 14$ for individuals or $£ 18$ for organisations. For further details about subscribing or for a copy of the Guidelines for Writers, contact Helen Imam, OPENMIND, (reference Psychiatric Bulletin), MIND, Granta House, 15-19 Broadway, London E15 4BQ telephone 0815192122.

\section{New publications}

Evaluating the NHS Reforms is published by the King's Fund Institute and brings together the results of seven in-depth research projects which examined key aspects of the NHS reforms from 1990 to 1993. It is avallable from BEPC, PO Box 1496. Poole, Dorset BH12 3YD; price £9.95 (paperback), £25.00 (hardback), both post free. Telephone orders: 0202 715555; fax orders 0202715556.

How to Look After Yourself is the first in a new mental health promotion series which aims to give the basic information necessary to safeguard mental health and provides addresses of where to go should problems arise. Other subjects to be covered in the series include panic attacks, suicide and insomnia. Copies, priced 45p, are avallable from MIND Publications, 15-19 Broadway, London E15 4BQ - please add $10 \%$ for post and packing.

\section{Call for papers}

The Journal of Mental Health Administration, the official publication of the Association of Mental Health Administrators, is a peer reviewed publication seeking manuscripts on mental health and substance abuse outcomes research. The deadline for manuscript submissions is 1 June 1994 and further information is available from Dr Bruce Lubotsky Levin, Editor, Journal of Mental Health Administration, Florida Mental Health Institute, University of South Florida, 13301 Bruce B. Downs Boulevard, Tampa, FL 33612-3899, USA (telephone 813974 6400; fax 813974 4406). 